19 Revue d'histoire du XIXe siècle

Société d'histoire de la révolution de 1848 et des

révolutions du XIXe siècle

13 | 1996

(Re)penser le XIXe siècle

\title{
Imaginaire littéraire et histoire des mentalités
}

\author{
Max Milner
}

URL: http://journals.openedition.org/rh19/102

DOI: $10.4000 /$ rh19.102

ISSN: $1777-5329$

Publisher

La Société de 1848

Printed version

Date of publication: 1 December 1996

ISSN: 1265-1354

Electronic reference

Max Milner, «Imaginaire littéraire et histoire des mentalités », Revue d'histoire du XIXe siècle [Online],

13 | 1996, Online since 10 September 2008, connection on 22 April 2019. URL : http:// journals.openedition.org/rh19/102 ; DOI : 10.4000/rh19.102

This text was automatically generated on 22 April 2019

Tous droits réservés 


\title{
Imaginaire littéraire et histoire des mentalités
}

\author{
Max Milner
}

\section{ABSTRACTS}

No abstract available by now

Pas de résumé disponible actuellement

INDEX

Mots-clés: Penser le dix-neuvième siècle, Mentalités, Littérature 